\title{
EFFECT OF TEMPERATURE VARIATION ON THE CYTOTOXICITY OF CAST DENTAL ALLOYS AND COMMERCIALLY PURE TITANIUM
}

\author{
Adriana Cláudia Lapria FARIA ${ }^{1}$, Renata Cristina Silveira RODRIGUES ${ }^{2}$, Rossana Pereira de Almeida ANTUNES ${ }^{3}$, \\ Maria da Gloria Chiarello de MATTOS ${ }^{4}$, Adalberto Luiz ROSA ${ }^{5}$, Ricardo Faria RIBEIRO ${ }^{6}$
}

\author{
1- DDS, MSc, Graduate student, Department of Dental Materials and Prosthodontics, Ribeirão Preto Dental School, University of São Paulo, Ribeirão \\ Preto, SP, Brazil. \\ 2- DDS, MSc, PhD, Assistant Professor, Department of Dental Materials and Prosthodontics, Ribeirão Preto Dental School, University of São Paulo, \\ Ribeirão Preto, SP, Brazil. \\ 3- DDS, MSc, PhD, Associate Professor, Department of Dental Materials and Prosthodontics, Ribeirão Preto Dental School, University of São Paulo, \\ Ribeirão Preto, SP, Brazil. \\ 4- DDS, MSc, PhD, Full Professor, Department of Dental Materials and Prosthodontics, Ribeirão Preto Dental School, University of São Paulo, \\ Ribeirão Preto, SP, Brazil. \\ 5- DDS, MSc, PhD, Associate Professor, Department of Oral and Maxillofacial Surgery and Periodontology, Ribeirão Preto Dental School, University \\ of São Paulo, Ribeirão Preto, SP, Brazil. \\ 6- DDS, MSc, PhD, Full Professor, Department of Dental Materials and Prosthodontics, Ribeirão Preto Dental School, University of São Paulo, \\ Ribeirão Preto, SP, Brazil.
}

Corresponding address: Ricardo Faria Ribeiro, Departamento de Materiais Dentários e Prótese - Faculdade de Odontologia de Ribeirão Preto - USP Av. do Café, s/n, 14040-904 - Ribeirão Preto, SP - Brasil - Phone: + 551636024046 - Fax: + 551636330999 - e-mail: rribeiro@forp.usp.br

Received: June 27, 2008 - Modification: August 31, 2008 - Accepted: October 7, 2008

\begin{abstract}
C of temperature variation on the cytotoxicity of dental alloys has not been analyzed. Objective: The aim of the present study was to investigate if temperature variation could affect dental alloy cytotoxicity, testing alloy extracts in an epithelial cell culture system. Material and methods: Discs of Ni-Cr, Co-Cr-Mo, Ni-Cr-Ti, Ti-6Al-4V and commercially pure titanium (cp Ti) were cast by arc melting, under argon atmosphere, injected by vacuum-pressure. Discs were immersed in artificial saliva and subjected to different temperatures: $37^{\circ} \mathrm{C}$ and thermocycling $\left(37^{\circ} \mathrm{C} / 5^{\circ} \mathrm{C} / 37^{\circ} \mathrm{C} / 55^{\circ} \mathrm{C} / 37^{\circ} \mathrm{C}\right)$. After thermocycling, extracts were put in a subconfluent culture during $6 \mathrm{~h}$, and the number of cells and their viability were used to evaluate cytotoxicity in these temperatures. For each alloy, data from temperature conditions were compared by Student's t-test $(\alpha=0.05)$. Results: The cytotoxicity tests with alloy/metal extracts showed that Ni-Cr, Co-Cr-Mo, Ti-6Al-4V and cp Ti extracts ( $>0.05)$ did not affect cell number or cell viability, while Ni-Cr-Ti $(p<0.05)$ extract decreased cell number and viability when the alloy was subjected to thermocycling. Conclusion: Within the limitations of the present study, the $\mathrm{Ni}-\mathrm{Cr}$-Ti alloy had cell number and viability decreased when subjected to temperature variation, while the other alloys/metal extracts did not show these results.
\end{abstract}

Key words: Dental alloys. Titanium. Biocompatible materials.

\section{INTRODUCTION}

Metals are subjected to biodegradation in the oral environment by dissolution in saliva, chemical/physical destruction, wear and erosion caused by food, chewing and bacterial activity, humidity, variation of temperature and $\mathrm{pH}^{1,7,14}$. The metallic ions released into the oral cavity will be in contact with adjacent cells and tissues and can be distributed to the body through blood vessels. As a consequence, adverse reactions like toxicity, allergy and mutagenicity can appear. The concentration and exposure time are critical for the toxicity reactions expressed as xerostomia, cheilitis, metallic taste and local erosion of the oral mucous membranes ${ }^{9}$. Some authors have reported that the incidence of toxicity reactions was higher among patients that had the largest number of restorations and had restorations that had been in service for more than 5 years ${ }^{9,19}$.

Dental alloys may contain nickel, chromium, cobalt and aluminum. Although these metals may cause hypersensitivity reactions and have been associated with allergy and adverse reactions in sensitive patients ${ }^{1,9,14}$, alloys containing these non-precious metals have been used over the past 25 years, when the price of noble metals was deregulated ${ }^{20}$. Therefore, in recent years, the use of titanium for dental applications 
has increased because of its biocompatibility, good resistance to corrosion and advantageous physical properties ${ }^{12,18}$.

In the oral environment, temperature changes may be induced by routine eating, drinking and breathing ${ }^{2,17}$, but there are no studies investigating whether temperature variation affects cytotoxicity of dental alloys. Once temperature variation is pointed as one of the factors associated to metals biodegradation in the oral environment, it is important to investigate if the ions released could affect cytotoxicity when metals are subject to temperature variations.

Cell culture system has been used to evaluate alloy cytotoxicity. When the cumulative effect of ions released in the environment where the alloys or metals are immersed is studied, extracts are tested ${ }^{16,21-23}$. In view of the aforementioned issues, the hypothesis tested is that temperature variation could interfere with ion release, affecting cytotoxicity. Therefore, the purpose of this study was to investigate if temperature variation could affect the cytotoxicity of dental alloys by evaluating alloy extracts in an epithelial cell culture system.

\section{MATERIAL AND METHODS}

The dental alloys and titanium used in the present study, their compositions and indications are presented in Figure 1. These materials are used in fixed partial dentures (FPD), removable partial dentures (RPD) or both.
Ten discs were obtained from wax patterns $(13 \mathrm{~mm}$ diameter and $4 \mathrm{~mm}$ thickness) that were invested and cast from different alloys and grade 1 commercially pure titanium (cp Ti). Ni-Cr, Co-Cr-Mo and Ni-Cr-Ti were invested with the phosphate based investment Rema Exakt (Dentaurum; Pforzheim, Baden-Württemberg, Germany) while Ti-6Al$4 \mathrm{~V}$ and cp $\mathrm{Ti}$ were invested with Rematitan Plus (Dentaurum).The discs were cast by arc melting in a vacuum and argon inert atmosphere, with injection of the alloy/metal into the mold by vacuum-pressure, in the machine Discovery Plasma (EDG Equipamentos e Controles Ltda., São Carlos, SP, Brazil).

After casting, the discs were divested and subjected to air-particle abrasion with $100-\mu \mathrm{m}$ aluminum oxide particles $\left(80 \mathrm{psi}=5.62 \mathrm{kgf} / \mathrm{cm}^{2}\right)$, then polished with $320-, 400-, 600$ , 1200-, 1500- and 2000-grit silicon carbide papers and the final polishing was done with diamond $(0.3,0.25$ and 0.1 $\mu \mathrm{m})$ and aluminum oxide $(1,0.5$ and $0.3 \mu \mathrm{m})$ pastes. The final polishing of $\mathrm{cp}$ Ti and Ti-6Al-4V were reached with a colloidal silica solution presenting a grain size of approximately $0.04 \mu \mathrm{m}$ and a $\mathrm{pH}$ of about 9.8 (OP-S Suspension, Struers A/S, Ballerup, Denmark) $+\mathrm{H}_{2} \mathrm{O}_{2} 30 \%$, suited for very ductile materials.

SCC 9 cells (ATCC) 30-32nd passage were cultured in D-MEM/Ham's F12 (Gibco Life Technologies, Grand Island, NY USA) supplemented with $10 \%$ fetal bovine serum (Gibco), $50 \mu \mathrm{g} / \mathrm{mL}$ gentamycin (Gibco) or $50 \mu \mathrm{g} / \mathrm{mL}$ vancomycine (Acros Organics, New Jersey, NJ, USA)/20 $\mu \mathrm{g} / \mathrm{mL}$ ampicillin (USB Corporation, Cleveland, $\mathrm{OH}, \mathrm{USA}$ ),

\begin{tabular}{|c|c|c|c|c|}
\hline $\begin{array}{l}\text { Alloy/metal } \\
\text { (base) }\end{array}$ & Indication* & Trade Name & $\begin{array}{l}\text { Manufacturer } \\
\text { (Batch number) }\end{array}$ & $\begin{array}{l}\text { Composition * } \\
\text { (\% weight) }\end{array}$ \\
\hline $\mathrm{Ni}-\mathrm{Cr}$ & FPD & Vera Bond II & $\begin{array}{l}\text { Aalba, USA } \\
(960502)\end{array}$ & $\begin{array}{l}\mathrm{Ni}-75.55 \%(\text { Max.); } \mathrm{Cr}- \\
11.50 \% \text {; Mo-3.50\%; Si- } \\
\text { 3.50\%; Nb-4,025\%; Al- } \\
2.25 \%\end{array}$ \\
\hline Co-Cr-Mo & RPD & ModellguB & $\begin{array}{l}\text { Degudent, Brazil } \\
\text { (14450) }\end{array}$ & $\begin{array}{c}\text { Co-64\%; Cr-28\%; Mo-5\%; } \\
\text { Others-5\% }\end{array}$ \\
\hline $\mathrm{Ni}-\mathrm{Cr}-\mathrm{Ti}$ & FPD & Tilite Ômega & $\begin{array}{l}\text { Talladium, USA } \\
\quad(071604)\end{array}$ & $\begin{array}{l}\text { Ni-60-76\%; Cr-12-21\%; } \\
\text { Mo-4-14\%; Ti-4-6\% }\end{array}$ \\
\hline $\begin{array}{l}\text { Commercially } \\
\text { pure titanium }\end{array}$ & $\begin{array}{l}\text { FPD } \\
\text { RPD }\end{array}$ & $\begin{array}{c}\text { Tritan } \\
\text { (Grade } 1 \text { ASTM) }\end{array}$ & $\begin{array}{l}\text { Dentaurum, } \\
\text { Germany (330307) }\end{array}$ & $\begin{array}{c}\text { Ti-99.48\%; O-0.18\%; Fe- } \\
0.2 \% ; \mathrm{H}-0.01 \% ; \mathrm{C}-0.1 \% \\
\text { N-0.03\% }\end{array}$ \\
\hline Ti-6AI-4V & $\begin{array}{l}\text { FPD } \\
\text { RPD }\end{array}$ & - & $\begin{array}{c}\text { RMI Co., USA } \\
\text { (TI20.00G2BF00104A) }\end{array}$ & $\begin{array}{c}\text { Ti-89.57\%; N-0.02\%; C- } \\
0.01 \% ; \mathrm{H}-0.003 \% ; \mathrm{Fe}- \\
0.22 \% ; \text { O-0.17\%; Al-6.2\%; } \\
\text { V-3.8\% }\end{array}$ \\
\hline
\end{tabular}

FIGURE 1- Alloys and metals evaluated with their indications, trade names, manufacturers, batch numbers and chemical compositions

${ }^{*}$ According to manufacturer. 
$0.3 \mu \mathrm{g} / \mathrm{mL}$ fungizone (Gibco) and $0.4 \mu \mathrm{g} / \mathrm{mL}$ hydrocortisone (Sigma Chemical Co, St. Louis, MO, USA) in $75 \mathrm{~cm}^{2}$ flasks (Fisher Scientific, Pittsburgh, PA, USA), until reaching the subconfluence, when cells were sprayed at $75 \%$ of surface. During the culture period, cells were incubated at $37^{\circ} \mathrm{C}$ in a humidified atmosphere of $5 \%$ carbon dioxide and $95 \%$ air, and the medium was changed every $48 \mathrm{~h}$.

To evaluate if temperature variation, one of the oral conditions related to degradation of materials ${ }^{1}$, interferes with the biocompatibility of dental alloys/metals, the Ni$\mathrm{Cr}$, Co-Cr-Mo, Ni-Cr-Ti, Ti-6Al-4V and cp Ti discs were immersed in artificial saliva (pH 5.5) ${ }^{5}$, into glass tubes with caps. The proportion between superficial area and volume of extraction vehicle, the artificial saliva, was 0.5 , according to ISO 10993-5 Part 5: Citotoxicity tests - in vitro methods ${ }^{11}$.

The discs and tubes were cleaned and autoclaved, the artificial saliva was filtered and the tubes were prepared in a laminar flow cabinet to maintain the aseptic condition during the extraction. The temperature variation was simulated by submitting the tubes to 1700 thermal cycles, which simulated the oral condition in approximately 4 months ${ }^{6}$. In a cycle, the tubes were maintained in $37^{\circ} \mathrm{C}, 5^{\circ} \mathrm{C}$, $37^{\circ} \mathrm{C}, 55^{\circ} \mathrm{C}, 37^{\circ} \mathrm{C}$ in this respective sequence 6 , $3 \mathrm{~min}$ in each temperature, time enough for the artificial saliva reaches the temperatures desired. When the cycles were interrupted, the tubes were maintained in $37^{\circ} \mathrm{C}$ until the cycles were started again. The 1,700 cycles lasted a 24 -day period. At the same period, tubes containing discs and artificial saliva were prepared and maintained at $37^{\circ} \mathrm{C}$ to be compared to thermocycled extracts. After thermal cycling period, the discs and artificial saliva were separated and the extracts were stored for cytotoxicity tests.

To determine if the artificial saliva was not cytotoxic to be used as extract vehicle and the ideal contact period of extracts with cell culture, a previous experiment was performed seeming $1.5 \times 10^{4}$ cells per well in 24-well culture plates until reaching the subconfluence, after 10 days, when medium was replaced by $1 \mathrm{~mL}$ of saliva. After periods of 2 , 4,6 and $24 \mathrm{~h}$ in contact with artificial saliva, the adherent cells were then enzymatically released $(1 \mathrm{mmol} / \mathrm{L}$ ethylenediaminetetraacetic acid [EDTA] and 0.25\% trypsin, Gibco) from the wells and counted using a hemacytometer and the results were compared to wells with culture medium, used as control. The cell number was expressed as a percentage of the number of cells in the control. Cell viability was evaluated using aliquots $(100 \mathrm{~mL})$ of the same solutions used for calculating the number of cells. These aliquots were incubated with $1 \%$ trypan blue (Sigma) during 5 min and non-viable cells were counted in a hemacytometer. Cell viability was expressed as percentage of the viable cells in the total number of cells. The data were subjected to ANOVA and the Tukey's multiple-range test. The period, whose cell number and cell viability were not statistically different from the control, was determined as ideal contact period.

After the former experiment, the cytotoxicity tests were made by testing the alloy/metal extracts in cell culture. For this, $1.5 \times 10^{4}$ cells per well were cultured in the same medium in 24-well culture plates until reaching the subconfluence in 10 days, as in the former experiment. After this, the medium was removed from each well and replaced by the extracts, previously filtered in a membrane filter (Puradisc, 0.2- $\mu \mathrm{m}$ pore size, Whatman, Clifton, NJ, USA). Wells without extracts were used as culture control. After a 6-h period, determined by the previous experiment, the number of cells and cell viability were evaluated following the method described above. The cell number was expressed as a percentage of the number of cells in the culture control, and cell viability as percentage of viable cells in the total number of cells.

The data presented are results of an experiment with $\mathrm{n}=$ 4 for each group. For each alloy, data from temperature conditions were compared by Student's t-test, Differences at $\mathrm{p}<0.05$ were considered statistically significant.

\section{RESULTS}

The results of the experiment that evaluated the artificial saliva cytotoxicity and the ideal contact period with cell culture are presented in Figures 2 (cell number) and 3 (cell

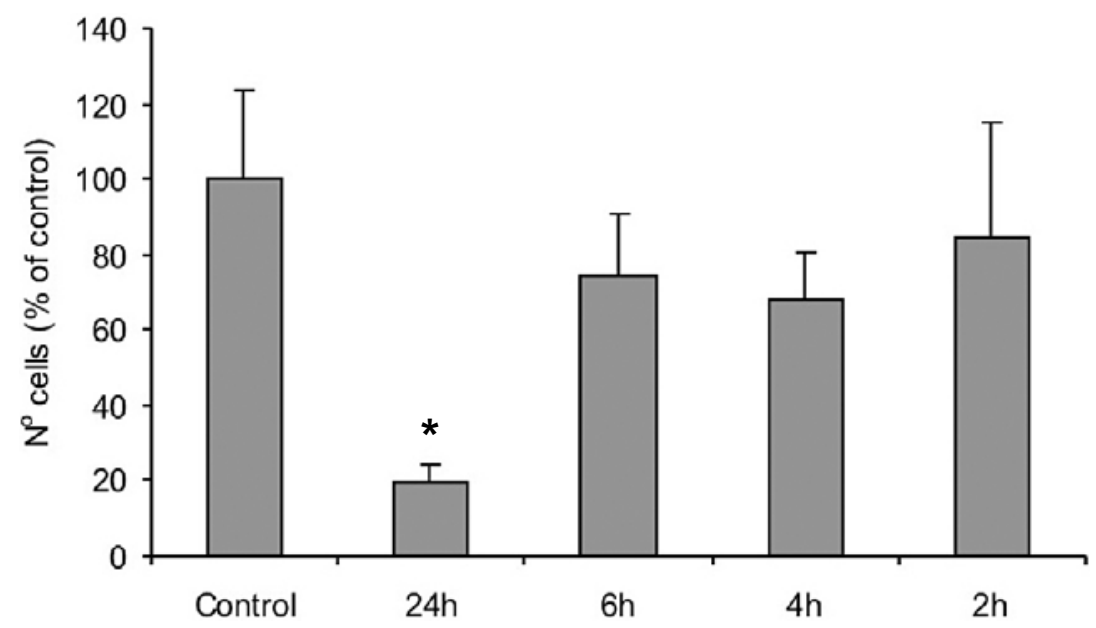

FIGURE 2- Number of cells counted in contact with artificial saliva over 2, 4, 6 and $24 \mathrm{~h}$, expressed as percentage of control. Data are shown as mean and bar indicates standard deviation $(n=4) .{ }^{*}$ statistically different from all the other groups 


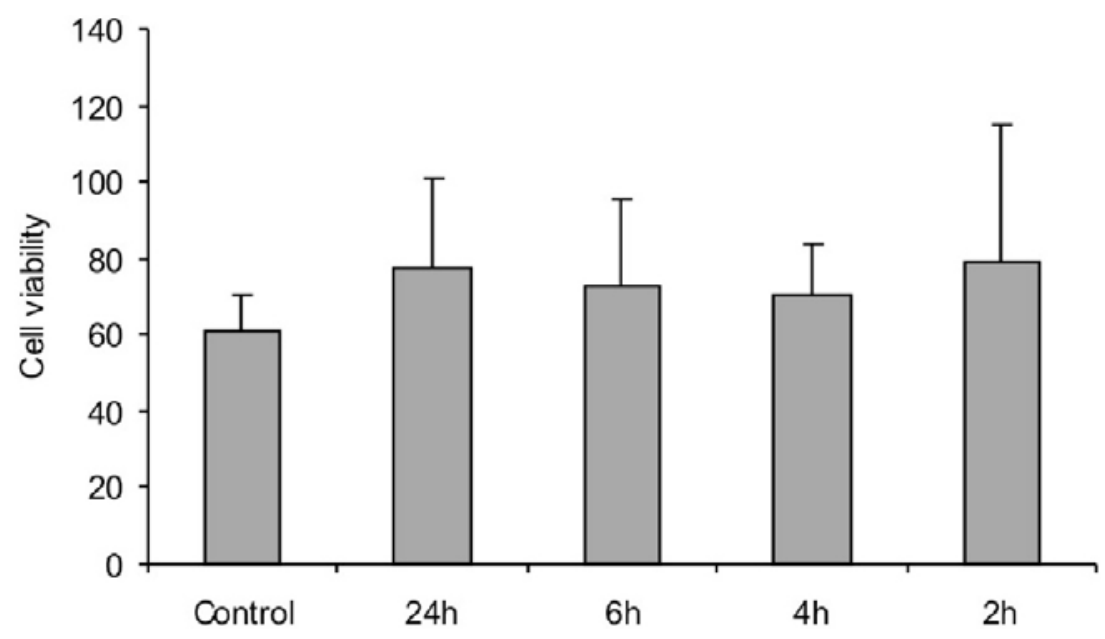

FIGURE 3- Number of viable cells counted in contact with artificial saliva over 2, 4, 6 and $24 \mathrm{~h}$, expressed as percentage of the viable cells in the total number of cells. Data are shown as mean and bar indicates standard deviation $(n=4)$

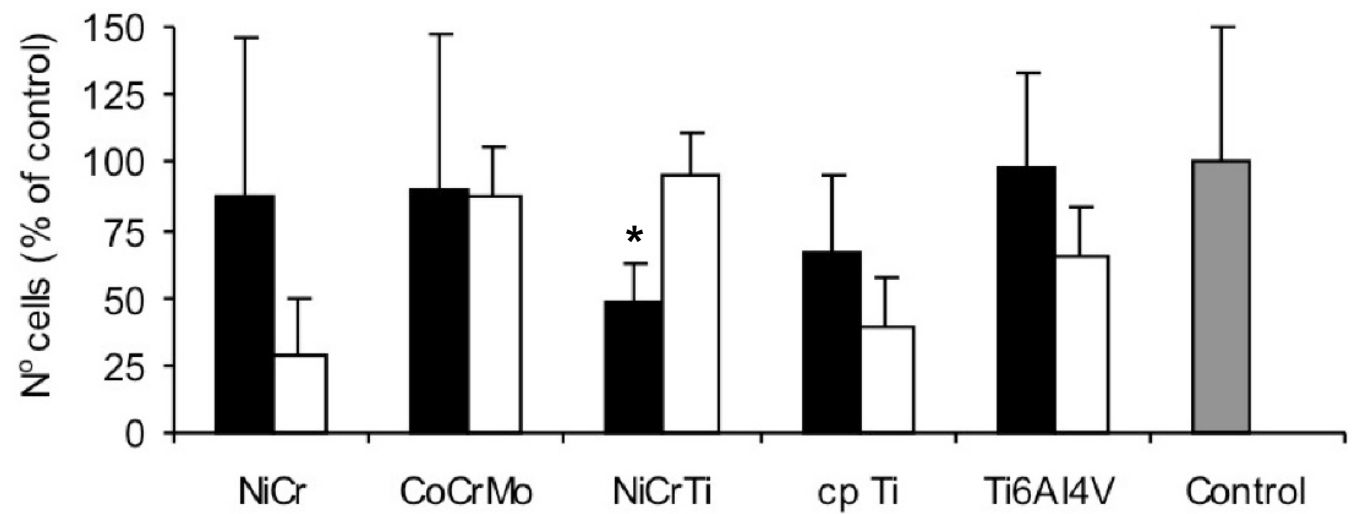

Thermocycled

Temperature $37^{\circ} \mathrm{C}$

FIGURE 4- Number of cells counted after 6-h contact with alloys and metal extracts, expressed as percentage of control. Data are shown as mean and bar indicates standard deviation $(n=4) .{ }^{*}$ statistically different from $37^{\circ} \mathrm{C}$

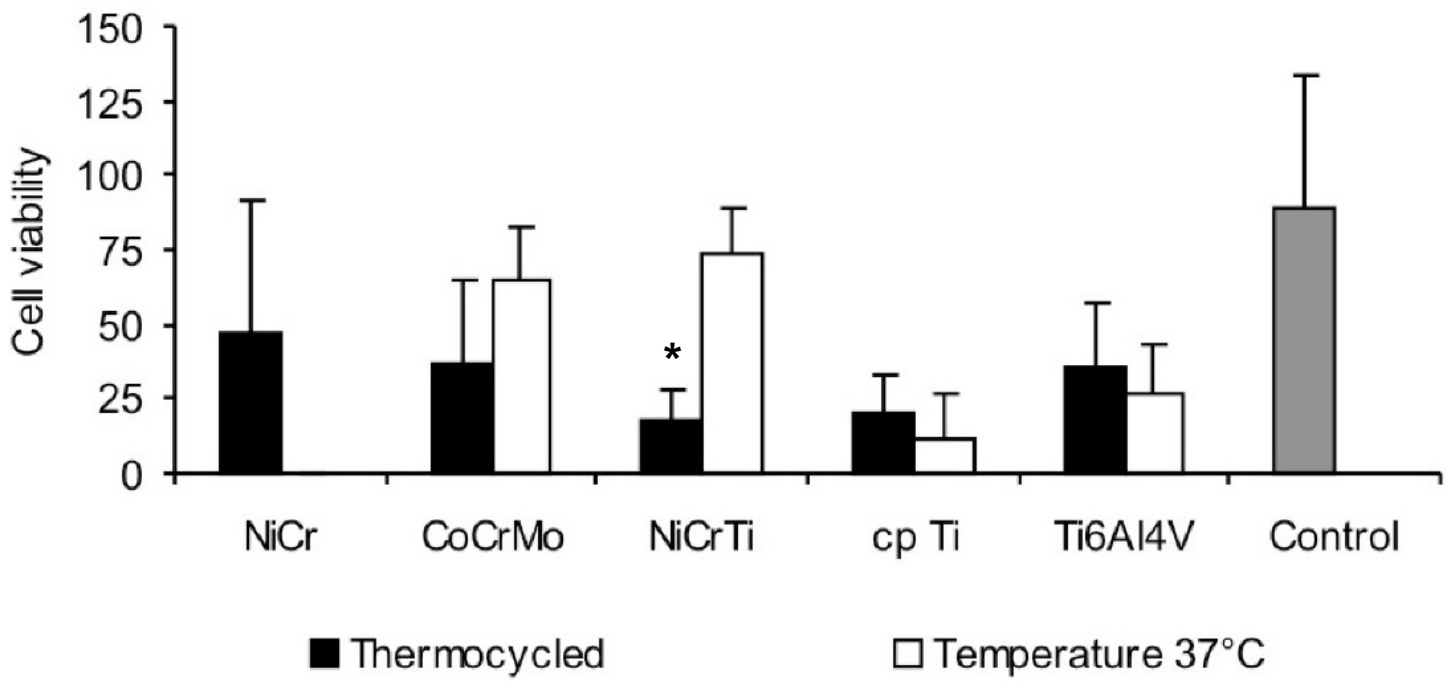

FIGURE 5- Number of viable cells counted after 6-h contact with alloys and metal extracts, expressed as percentage of the viable cells in the total number of cells. Data are shown as mean and bar indicates standard deviation $(n=4)$. * statistically different from $37^{\circ} \mathrm{C}$ 
viability). The 24 -h period was statistically different from the other periods and control in the cell number $(\mathrm{p}=0.001)$, but the cell viability was not affected by the contact period or saliva $(\mathrm{p}=0.808)$. Therefore, it was decided that saliva could be used as extraction vehicle and the contact period for tests would be 6-h.

Cell number and viability in the cytotoxicity tests with alloy/metal extracts are presented, respectively, in Figures 4 and 5 . The cytotoxicity tests with alloy/metal extracts have shown that Ni-Cr $(\mathrm{p}=0.114)$, Co-Cr-Mo $(\mathrm{p}=0.915)$, Ti-6Al$4 \mathrm{~V}(\mathrm{p}=0.153)$ and $\mathrm{cp} \mathrm{Ti}(\mathrm{p}=0.162)$ extracts have not affected cell number while $\mathrm{Ni}-\mathrm{Cr}-\mathrm{Ti}(\mathrm{p}=0.006)$ extract has decreased the number of cells when the alloy was subjected to thermocycling. Similar results were found for cell viability; $\mathrm{Ni}-\mathrm{Cr}$-Ti extract $(\mathrm{p}=0.001)$ had the cell viability decreased after thermocycling, while $\mathrm{Ni}-\mathrm{Cr}(\mathrm{p}=0.126)$, Co-Cr-Mo $(p=0.149)$, Ti-6Al-4V $(p=0.528)$ and $c p$ Ti $(p=0.436)$ extracts did not.

\section{DISCUSSION}

Cell culture tests have been used to evaluate materials that will be in contact with body tissues. Dental alloys are suitable to biodegradation and dissolution in oral environment, and the ions released from dental alloys could result in toxicity, allergy or systemic adverse reactions because of the absorption in oral mucosa, skin, digestive tract and respiratory system.

Cytotoxicity tests with extracts were used in studies that evaluated the effect of time and environment on the alloy biocompatibility ${ }^{8,16}$. In the present study, artificial saliva was used as an extract vehicle in order to simulate the oral condition. However, a previous experiment had to be performed to evaluate the artificial saliva viability in cell culture conditions once composition and $\mathrm{pH}$ different from culture medium could affect cell culture. As the results of the previous experiment showed that the presence of artificial saliva in culture did decrease significantly cell number in periods of 2, 4 and $6 \mathrm{~h}$, the 6 -h period was determined as the ideal contact period. Cell number was affected in $24-\mathrm{h}$ period, but the same did not happen in cell viability, which was statistically similar in all evaluated periods. A probable reason for this is that the 24-h contact with artificial saliva interfered with adhesion mechanism of cells and cells released from culture surface instead of having cell activity affected.

In the present study, base-metal alloys were immersed in artificial saliva and subjected to temperature change, as in the oral environment, and the effect of temperature variation on alloy cytotoxicity was evaluated with extracts, once ions released by alloy degradation and dissolution could affect alloy biocompatibility. Because in cell culture conditions the temperature is always maintained in $37^{\circ} \mathrm{C}$, the effect of temperature variation in ion release from the metals/alloys could only be evaluated by extracts.

The environment where the material is immersed influences the releasing rate of the metallic ions, as a study, after comparing D-MEM, saline and saline with 3\% bovineserum-albumin, related the effect of the protein present in these solutions increasing the ions release ${ }^{16}$. This fact could leave one to think that culture results would present lower cytotoxicity than mouth. However, there are several factors present in the mouth, like saliva, $\mathrm{pH}$, biofilm, oral rehabilitation with different metals, chewing and toothbrushing, and simulating all these conditions would be impossible.

Comparing alloy/metal extracts subjected to thermal cycles and maintained at $37^{\circ} \mathrm{C}$, it was noted that $\mathrm{Ni}-\mathrm{Cr}-\mathrm{Ti}$ extract had a decreased cell number and viability when discs were subjected to temperature variation, suggesting that $\mathrm{Ni}$ $\mathrm{Cr}-\mathrm{Ti}$ is more sensible to temperature variation. Although titanium has been added to $\mathrm{Ni}-\mathrm{Cr}$ alloys to improve biocompatibility, the content of $4 \%$ of Ti did not improve the corrosion resistance of these alloys though titanium oxide was found in the metal surface ${ }^{10}$. Temperature variation could interfere with passivation mechanism present in surface of the alloy disc, but other investigations are necessary to assume this hypothesis.

On the other hand, the biocompatibility of the other alloys was not affected significantly by temperature variation. A possible reason for Co-Cr-Mo extract biocompatibility is that Co-Cr-Mo alloys are referred as corrosion resistant due to chromium and molybdenum ${ }^{13,15}$, since the alloy content is at least $16-22 \% \mathrm{Cr}$ and $9-14 \% \mathrm{Mo}$ to have a stable passive layer ${ }^{10}$, avoiding ions release.

If chromium and molybdenum content present in CoCr-Mo alloys allow a passive layer formation, it could not occur in Ni-Cr alloys. Brune ${ }^{3}$ (1986) reported that the releasing rate in saliva was greater than in saline, while another study found that a drop in $\mathrm{pH}$ value increases ion release in $\mathrm{Ni}-\mathrm{Cr}$ alloys ${ }^{21}$. However, temperature variation did decrease significantly cell number and viability. Although no viable cells have been found when $\mathrm{Ni}-\mathrm{Cr}$ extracts in $37^{\circ}$ $\mathrm{C}$ were tested, the Ni-Cr thermocycled extracts presented high variability of the results and significant differences were not found between them.

The biocompatibility tests with extracts of the present study showed different results from those of experiments evaluating alloy biocompatibility by direct contact ${ }^{4}$. Some differences should be considered like an accumulation of ions in the extracts that will be put in culture tests with extracts, while in direct contact tests the solubilized ions are periodically removed in each medium change. Further studies evaluating extract compositions are necessary to clarify the reason for these results.

\section{CONCLUSIONS}

Within the limitations of the present study, it may be concluded that the Ni-Cr-Ti alloy had cell number and viability decreased when subjected to temperature variation, while the other alloys/metal extracts did not show these results. 


\section{ACKNOWLEDGMENTS}

The authors thank FAPESP (Grant \# 03/01775-4) for the financial support and Mr. Luiz Sérgio Soares, Mrs. Ana Paula Macedo, Mr. Roger Fernandes and Ms. Júnia Ramos for the technical support.

\section{REFERENCES}

1- Anusavice KJ. Phillip's science of dental materials. 11th ed Philadelphia: Elsevier; 2004.

2- Boehm RF. Thermal environment of teeth during open mouth respiration. J Dent Res. 1972;51:75-8.

3- Brune D. Metal release from dental biomaterials. Biomaterials. 1986; $7: 163-75$

4- Faria ACL, Rosa AL, Rodrigues RCS, Ribeiro RF. In vitro cytotoxicity of dental alloys and cp Ti obtained by casting. J Biomed Mater Res B Appl Biomater. 2008;85B:504-8.

5- Fusayama T, Katayori T, Nomoto S. Corrosion of gold and amalgam placed in contact with each other. J Dent Res. 1963;42:1183-97.

6- Gale MS, Darvell BW. Thermal cycling procedures for laboratory testing of dental restorations. J Dent. 1999;27:89-99.

7- Geis-Gerstofer J. In vitro corrosion measurements of dental alloys. J Dent. 1994;22:247-51

8- Grill V, Sandrucci MA, Di Lenarda R, Basa M, Narducci P, Martell $\mathrm{AM}$, et al. In vitro evaluation of the biocompatibility of dental alloys: fibronectin expression patterns and relationships to cellular proliferation rates. Quintessence Int. 2000;31:741-7.

9- Hensten-Pettersen A. Casting alloys: side effects. Adv Dent Res. 1992;6:38-43.

10- Huang HH. Effect of chemical composition on the corrosion behavior of Ni-Cr-Mo dental casting alloys. J Biomed Mater Res. 2002;60:458 65

11- International Organization for Standardization. ISO 10993-5. Biological evaluation of medical devices- Part 5- tests for cytotoxicity: in vitro methods. Geneva: The Organization; 1992.

12- Lautenschlager EP, Monaghan P. Titanium and titanium alloys as dental materials. Int Dent J. 1993;43:245-53.

13- Lin HY, Bumgardner JD. Changes in the surface oxide composition of Co-Cr-Mo implant alloy by macrophage cells and their released reactive chemical species. Biomaterials. 2004;25:1233-8.

14- Lygre H. Prosthodontic biomaterials and adverse reactions: a critical review of the clinical and research literature. Acta Odontol Scand. 2002;60:1-9.

15- Mareci D, Nemtoi GH, Aelenei N, Bocanu C. The eletrochemical behaviour of various non-precious $\mathrm{Ni}$ and $\mathrm{Co}$ based alloys in artificial saliva. Eur Cell Mater. 2005;10:1-7.

16- Nelson SK, Wataha JC, Lockwood PE. Accelerated toxicity testing of casting alloys and reduction of intraoral release of elements. J Prosthet Dent. 1999;81:715-20

17- Palmer DS, Barco MT, Billy EJ. Temperature extremes produced orally by hot and cold liquids. J Prosthet Dent. 1992;67:325-7.
18- Wang RR, Fenton AA. Titanium for prosthodontic applications: a review of the literature. Quintessence Int. 1996;27:401-8.

19- Wataha JC. Biocompatibility of dental casting alloys: a review. J Prosthet Dent. 2000; 83:223-34

20- Wataha JC. Alloys for prosthodontics restorations. J Prosthet Dent. 2002;87:351-63.

21- Wataha JC, Lockwood PE, Khajotia SS, Turner R. Effect of $\mathrm{pH}$ on element release from dental casting alloys. J Prosthet Dent. 1998;80:691-

22- Wataha JC, Lockwood PE, Nelson SK. Initial versus subsequent release of elements from dental casting alloys. J Oral Rehabil. 1999;26:798-803.

23- Watanabe I, Wataha JC, Lockwood PE, Shimizu H, Cai Z, Okabe T. Cytotoxicity of commercial and novel binary titanium alloys with and without a surface-reaction layer. J Oral Rehabil. 2004;31:185-9. 